\title{
How I diagnose and treat splenic lymphomas
}

\author{
*Emilio lannitto ${ }^{1}$ and ${ }^{*}$ Claudio Tripodo 2 \\ ${ }^{1}$ Department of Oncology, Haematology Unit, University of Palermo School of Medicine, Palermo, Italy; and ${ }^{2}$ Department of Health Sciences, Pathology Unit, \\ University of Palermo School of Medicine, Palermo, Italy
}

\begin{abstract}
The incidental finding of an isolated splenomegaly during clinical assessment of patients evaluated for unrelated causes has become increasingly frequent because of the widespread use of imaging. Therefore, the challenging approach to the differential diagnosis of spleen disorders has emerged as a rather common issue of clinical practice. A true diagnostic dilemma hides in distinguishing pathologic conditions primarily involving the spleen from those in which splenomegaly
\end{abstract}

presents as an epiphenomenon of hepatic or systemic diseases. Among the causes of isolated splenomegaly, lymphoid malignancies account for a relevant, yet probably underestimated, number of cases. Splenic lymphomas constitute a wide and heterogeneous array of diseases, whose clinical behavior spans from indolent to highly aggressive. Such a clinical heterogeneity is paralleled by the high degree of biologic variation in the lymphoid populations from which they originate. Neverthe- less, the presenting clinical, laboratory, and pathologic features of these diseases often display significant overlaps. In this manuscript, we present our approach to the diagnosis and treatment of these rare lymphomas, whose complexity has been so far determined by the lack of prospectively validated prognostic systems, treatment strategies, and response criteria. (Blood. 2011;117(9):2585-2595)

\section{Introduction}

Splenomegaly is a frequent yet challenging sign clinicians have to deal with in daily clinical practice. A true diagnostic dilemma hides in distinguishing pathologic conditions primarily involving the spleen from those in which splenomegaly presents itself as an epiphenomenon of hepatic or systemic diseases. Moreover, because of the widespread use of ultrasonographic imaging, physicians often have to face such a diagnostic challenge in the setting of patients in whom the incidental finding of a slight isolated splenomegaly may be the only sign of an underlying disease.

Among the causes of isolated splenomegaly, malignant lymphomas account for a relevant, yet probably underestimated, number of cases. As a secondary lymphoid organ, the spleen may be involved by lymphoid neoplasms during their dissemination process. However, it rarely represents the exclusive site of the lymphomatous burden. Basing on a mere anatomic criterion, the designation "splenic lymphomas" (SLs) has been classically restricted to neoplasms fulfilling this latter condition. ${ }^{1}$ Herein, we adopt a less restrictive definition of SLs encompassing cases presenting with splenic involvement and in which the disease may also extend to the bone marrow (BM), peripheral blood (PB), and/or the liver, in the absence of prominent lymph node involvement. ${ }^{2,3}$

In the present era of detailed biologic characterization of lymphoid populations, the aforementioned categorization of SLs may sound leaky. Indeed, SLs are composed of a wide and heterogeneous array of diseases, whose clinical behavior spans from indolent to highly aggressive (Table 1 ). The clinical heterogeneity of these lymphomas is paralleled by the high degree of biologic variation in the lymphoid populations from which they originate. ${ }^{4}$ Nevertheless, the presenting clinical, laboratory, and pathologic features of such lymphoid malignancies display significant overlaps, which justify grouping diverse entities under the same "operative heading" of SLs.
In this manuscript, we present our diagnostic and therapeutic approach to these rare malignancies (accounting for $\sim 6 \%$ of all lymphoid neoplasms), whose complexity has been so far determined by the lack of prospectively validated prognostic systems, treatment strategies, and response criteria.

\section{Diagnostic workup}

The clinical presentation of patients with SLs is varied, composing truly asymptomatic patients with isolated splenomegaly, patients in whom splenomegaly is associated with PB count changes, and patients reporting constitutional symptoms and/or abdominal discomfort secondary to massive spleen enlargement. Such nonspecific pictures often cause patients to undergo extensive investigation for infective, hepatic, or hemolytic diseases by physicians of diverse subspecialties before a lymphoid malignancy is suspected (Table 2).$^{5}$ In the subset of patients in which splenomegaly remains "unexplained," lymphomas account for the leading cause (Table 3). 6-8

When approaching patients with suspect SLs, our primary effort is to achieve a diagnosis by integrating presenting clinical and laboratory data with imaging, $\mathrm{PB}$, and BM assessment, thus trying to avoid splenectomy for diagnostic purposes. The main steps of our diagnostic workup of SLs are schematically represented in Figure 1.

\section{Clinical evidence}

We always collect a detailed medical history, which is mainly aimed to highlight the presence of specific clues that may be
${ }^{\star}$ E.I. and C.T. contributed equally to this study.

C 2011 by The American Society of Hematology 
Table 1. Lymphoid malignancies that may present as SLs

\begin{tabular}{l} 
Lymphomas commonly/typically presenting as SLs $^{\star}$ \\
SMZL \\
SL-u \\
Splenic diffuse red pulp B-cell lymphoma \\
HCL variant \\
HCL \\
LL \\
B-PLL \\
T-LGL \\
Hepatosplenic T-cell lymphoma \\
Primary splenic presentations ${ }^{*}$ of nodal lymphomas \\
MCL \\
FL \\
DLBCL-not otherwise specified \\
Micronodular T-cell/histiocyte-rich large B-cell lymphoma \\
\hline
\end{tabular}

*Splenic presentation encompasses cases with splenic involvement and in which the disease may extend also to the BM, PB, and/or the liver, in the absence of prominent lymph node involvement.

relevant for the diagnosis and/or management of SLs. These include the presence of pathologic conditions, such as chronic hepatitis $\mathrm{C}$ virus (HCV) and hepatitis B virus infection, autoimmune disorders (eg, systemic lupus erythematosus, autoimmune thyroiditis), previous therapies with immunosuppressive agents or tumor necrosis factor blockers, B-symptoms, and symptoms evocative of a rapid and/or massive spleen enlargement, such as left-flank pain and feeling of abdominal fullness.

Some of this information may strengthen the suspicion of a lymphoproliferative disorder, and some may be oriented toward a specific diagnosis, such as anti-tumor necrosis factor treatment in young patients with Crohn disease, raising the suspicion of hepatosplenic T-cell lymphoma (HSTL), whereas some others might have an impact on the further steps of the diagnostic workup, such as the presence of $\mathrm{HCV}$ infection influencing the interpretation of the BM histopathologic picture. ${ }^{9-12}$

A careful scrutiny of the patient's past medical investigations should always be performed. Specifically, any incidental finding of slight cytopenia, which could have been overlooked or neglected at routine checkup, should be noted and dated because it may

Table 2. Overview of the pathologic conditions, other than lymphomas, causing splenomegaly

\begin{tabular}{|c|c|}
\hline Disease type & Representative examples \\
\hline Infective & $\begin{array}{l}\text { Brucellosis, EBV and CMV infections, } \\
\text { Leishmaniasis, viral hepatitis }\end{array}$ \\
\hline Myeloproliferative neoplasms & PMF, CML, PV, CMML \\
\hline Hemolytic anemia & $\begin{array}{l}\text { Thalassemia, sickle cell anemia, } \\
\text { hereditary spherocytosis, autoimmune } \\
\text { hemolytic anemia }\end{array}$ \\
\hline $\begin{array}{l}\text { Hepatic diseases and veno- } \\
\text { occlusive disorders of hepatic } \\
\text { veins and portal system }\end{array}$ & $\begin{array}{l}\text { Cirrhosis, hepatic/portal/splenic vein } \\
\text { thrombosis }\end{array}$ \\
\hline $\begin{array}{l}\text { Autoimmune and inflammatory } \\
\text { diseases }\end{array}$ & $\begin{array}{l}\text { SLE, Felty syndrome, sarcoidosis, } \\
\text { inflammatory pseudotumor of the spleen }\end{array}$ \\
\hline Tumors & $\begin{array}{l}\text { Littoral cell angioma, hemangioma, } \\
\text { lymphangioma, spindle-cell sarcomas, } \\
\text { metastases }\end{array}$ \\
\hline $\begin{array}{l}\text { Protein misfolding diseases and } \\
\text { thesaurismoses }\end{array}$ & $\begin{array}{l}\text { Amyloidosis, Gaucher disease, Erdheim- } \\
\text { Chester disease }\end{array}$ \\
\hline Other conditions & Cysts, infarction \\
\hline
\end{tabular}

EBV indicates Epstein-Barr virus; CMV, cytomegalovirus; PMF, primary myelofibrosis; CML, chronic myelogenous leukemia; PV, polycythemia vera; CMML, chronic myelomonocytic leukemia; and SLE, systemic lupus erythematosus.
Table 3. Incidence of different pathologic conditions underlying unexplained splenomegaly, according to 3 recent diagnostic splenectomy series

\begin{tabular}{|c|c|c|c|}
\hline Disease type & $\begin{array}{l}\text { Kraus et al } \\
\quad(2001) \\
\text { no. }(\%)\end{array}$ & $\begin{array}{l}\text { Carr et al }{ }^{7} \\
(2002) \\
\text { no. }(\%)\end{array}$ & $\begin{array}{l}\text { Pottakkat et al }{ }^{8} \\
(2006) \\
\text { no. }(\%)\end{array}$ \\
\hline Lymphoid malignancies & $69 / 122(57)$ & $8 / 18(44)$ & $15 / 41(36.5)$ \\
\hline Infective & 0 & 0 & $8(19.5)$ \\
\hline Myeloproliferative neoplasms & $3(2.5)$ & 0 & 0 \\
\hline $\begin{array}{l}\text { Hepatic diseases and veno- } \\
\text { occlusive disorders of hepatic } \\
\text { veins and portal system }\end{array}$ & $2(1.5)$ & $6(33)$ & $16(39)$ \\
\hline $\begin{array}{l}\text { Autoimmune and inflammatory } \\
\text { diseases }\end{array}$ & $7(6)$ & $4(23)$ & 0 \\
\hline Tumors & $26(21)$ & 0 & $2(5)$ \\
\hline Other conditions & $15(12)$ & 0 & 0 \\
\hline
\end{tabular}

represent a precious insight into the presumptive onset and pace of an underlying lymphoproliferation.

By physical examination, little can be inferred other than signs related to spleen and/or liver enlargement because peripheral lymph node involvement is only exceptionally observed in the presentation of SLs. ${ }^{13-24}$ Nevertheless, we consistently complement physical examination with the ultrasonographic assessment of superficial lymphatic stations and abdomen to highlight any lymphadenomegaly that could be eventually considered for subsequent histologic analysis. ${ }^{25}$

Similar to clinical presentations, baseline laboratory findings of patients with SLs may be rather overlapping and thus poorly informative for diagnostic purposes. Indeed, PB counts may be normal or display slight to marked lymphocytosis with or without cytopenia (mostly anemia and thrombocytopenia) of variable degree, irrespective of the underlying lymphoma histotype. ${ }^{26}$ Together with $\beta_{2}$-microglobulin and lactate dehydrogenase, wellknown surrogates of the neoplastic burden, the presence of $\mathrm{HCV}$ infection, serum M component, and Coomb test should be consistently checked because of their high prevalence in some SL histotypes, such as splenic marginal zone lymphoma (SMZL). ${ }^{27,28}$

\section{Diagnostic imaging}

Most of the patients coming to our attention with a suspected SL have already undergone imaging assessment as part of the diagnostic workup for their underlying unexplained splenomegaly. Ultrasound (US) imaging of the abdomen and whole-body computed tomography scan are mandatory in all patients and must be performed on presentation when they are not already available.

B-mode US is adequate for determining the actual size of the spleen. ${ }^{29}$ Moreover, it can provide key pieces of information regarding the echo-texture of the splenic parenchyma, allowing the detection of focal lesions with a high sensitivity. ${ }^{30}$ By contrast, B-mode US displays poor sensitivity when a diffuse effacement of the spleen occurs. As a result, the overall sensitivity of B-mode US in the diagnosis of splenic lymphoma involvement is approximately $50 \%$. Contrast-enhanced US does not add much to the diagnostic potential of B-mode US when applied to the spleen ${ }^{31}$; therefore, we do not perform it routinely as part of the SL diagnostic workup.

As the "gold standard" investigation for clinical staging of lymphomas, whole-body computed tomography scan allows determining whether the suspected lymphoproliferative disorder is confined to the spleen or it involves other nodal and/or extranodal 


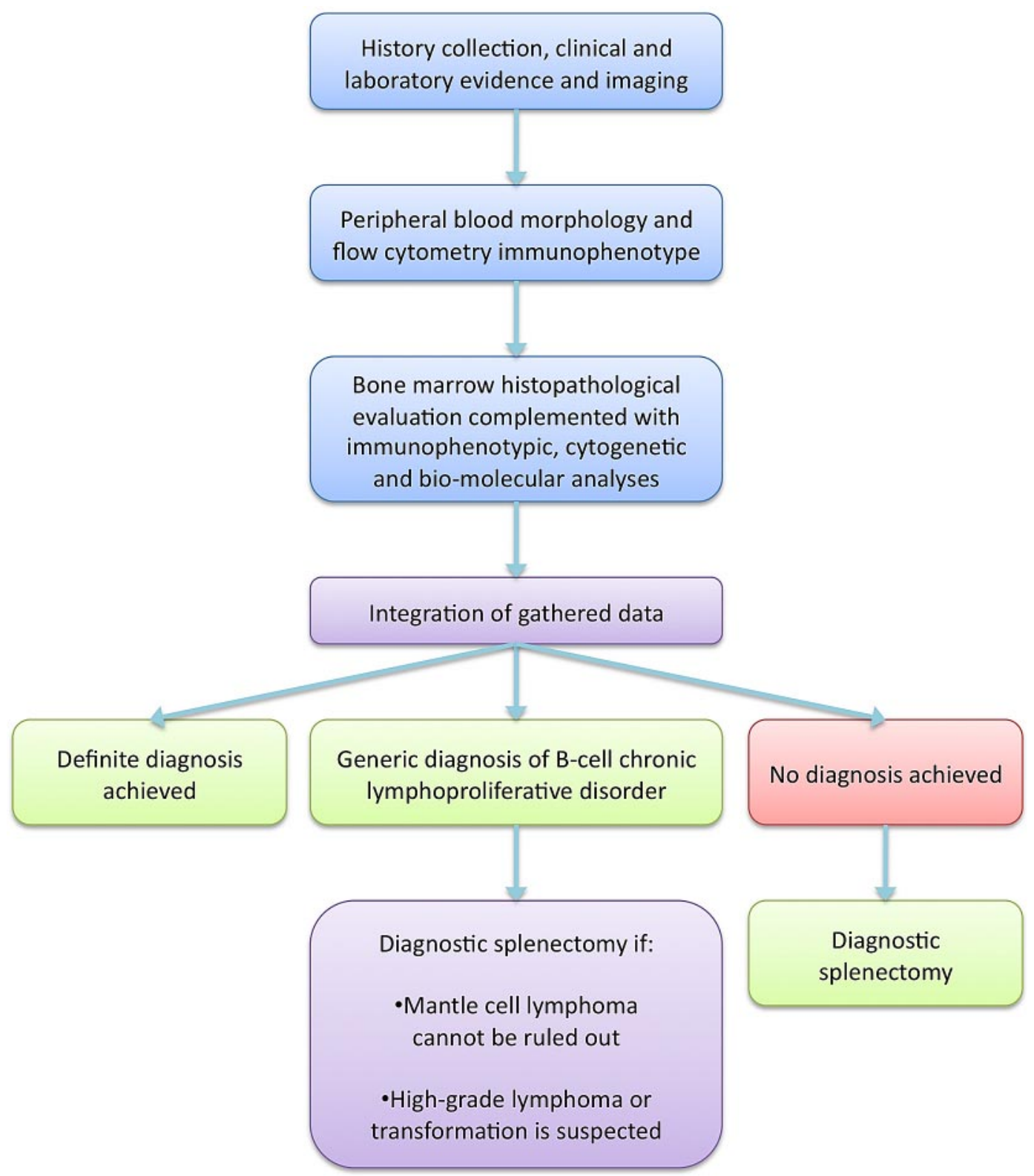

Figure 1. Schematic representation of the main steps of the SL diagnostic workup.

sites. Moreover, it represents an optimal complementary assessment of the spleen architecture to B-mode US. ${ }^{32}$

To date, there is no indication for routine fluorodeoxyglucose positron emission tomography scan in the diagnostic approach and staging of SLs; likewise, there is no routine role for magnetic resonance imaging. ${ }^{33,34}$ In our practice, fluorodeoxyglucose positron emission tomography is only performed as an integrative pretreatment staging procedure in high-grade SLs.

\section{PB evaluation}

Most of the entities included among SLs almost invariably show the presence of neoplastic cells in the PB. Such circulating components may rarely configure an overt leukemic picture or, more frequently, consist of a subtle spillover of splenic and marrow infiltrates, such as in some cases of SMZL or hairy cell leukemia (HCL). ${ }^{18,35,36} \mathrm{~PB}$ examination is therefore a mandatory step in the diagnostic workup of SLs. We pay particular attention to data that can be inferred by the morphologic evaluation of May-GrunwaldGiemsa-stained PB smears. On the one hand, it may allow the identification of peculiar cell types, such as hairy cells, prolymphocytes, villous lymphocytes, basophilic villous lymphocytes, large and granular lymphocytes, and plasmacytoid lymphocytes, which may trigger the suspicion of a specific lymphoproliferative disease (Figure 2). On the other hand, it may highlight the presence of atypical lymphoid populations, and this information may prove of value for the subsequent flow cytometric, histopathologic, and immunohistochemical analyses. Informative examples may be that of HSTL, which may show circulating atypical cells that can be overlooked on flow cytometry being commonly CD4 ${ }^{-} \mathrm{CD} 8^{-} \mathrm{T}$-cell receptor- $\alpha \beta^{-}$, and that of rare leukemic variants of follicular lymphomas displaying circulating "buttock" cells. ${ }^{12,37}$

By flow cytometry, the surface phenotype of the circulating component of SLs can be determined, and a definite diagnosis can 
HCL: Iymphocytes with oval eccentric nuclei and reticular chromatin showing abundant pale cytoplasm with fine, evenly distributed projections.

SMZL: medium sized lymphocytes with round nuclei, dispersed chromatin and abundant pale cytoplasm showing thick polar villi.

MCL: medium sized lymphocytes with indented nuclei, condensed chromatin and indistinct nucleoli (left); larger blastoid cells with reticular chromatin and one or two nucleoli (right).

LPL: large plasmacytoid lymphocytes with round nuclei, finely dispersed chromatin and rich basophilic cytoplasm (left); small round lymphocytes with denser chromatin and scanty cytoplasm (right).

B-PLL: medium to large cells with moderately condensed nuclear chromatin and prominent vescicular nucleoli, regular nuclear outline and weakly basophilic cytoplasm.

FL: small atypical lymphocytes with condensed chromatin, markedly irregular nuclear contours and deep nuclear grooves ("buttock cells").

T-LGL: medium sized cells with round nuclei and condensed or "ropey" chromatin, and ample cytoplasm with variable numbers of azurophilic granules.

HSTL: medium sized-to-large atypical lymphocytes with irregular nuclear contour, prominent nucleoli, and abundant cytoplasm that may contain scattered granules (right)
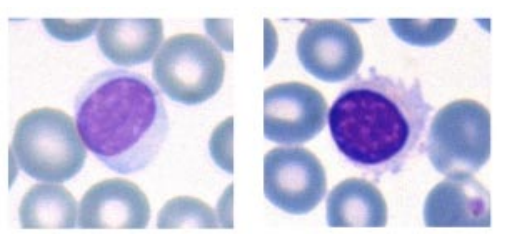

Figure 2. Morphologic clues of SL neoplastic cells in the PB. May-Grunwald-Giemsa stain: original magnification $\times 630$. Images were captured by a Leica DM 3000 optical microscope, Leica DFC 320 digital camera, and Leica IM50 software.
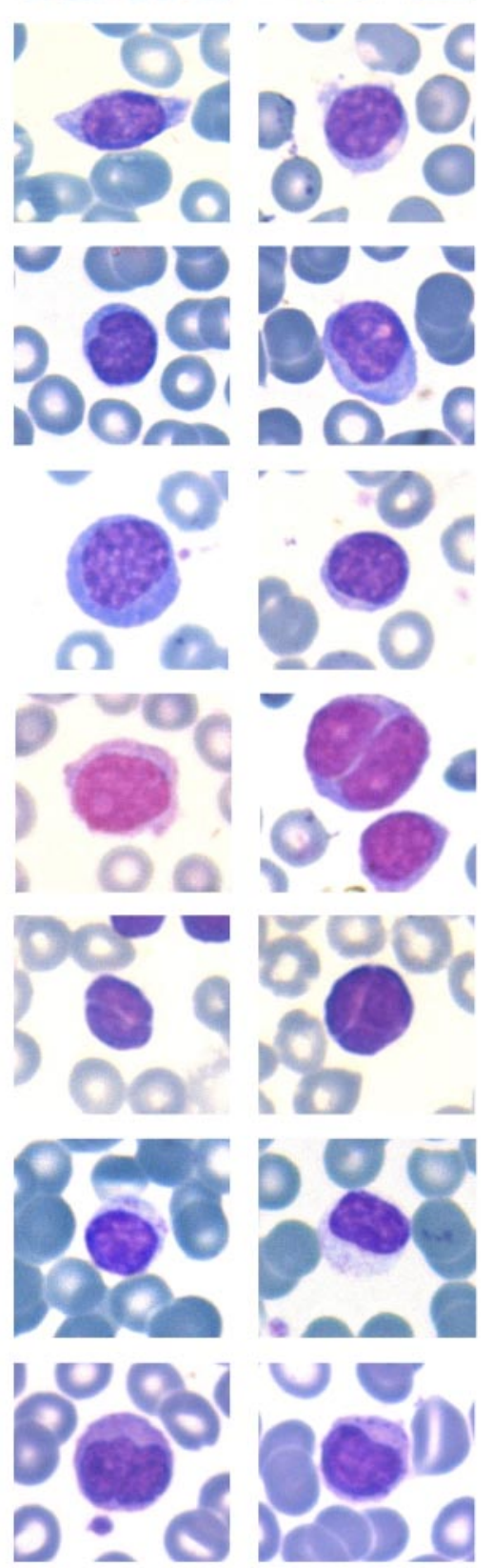

be performed in HCL, mantle cell lymphoma (MCL), and T-cell large granular lymphocytic leukemia (T-LGL), when all the expected immunophenotypic features of these neoplasms are present (Table 4) ${ }^{26,38}$ PB flow cytometry may also prove conclusive for the diagnosis of HSTL, provided that $\alpha \beta$ and $\gamma \delta$ T-cell receptor expression is tested on the basis of a specific clinical suspect. ${ }^{12}$ By contrast, in SMZL, splenic lymphoma/leukemia unclassifiable (SL-u), and lymphoplasmacytic lymphoma (LPL), a precise diagnosis may not be achieved by flow cytometry alone because of the lack of specific phenotypic markers (Table 4). ${ }^{39}$ In such cases, a generic diagnosis of B-cell chronic lymphoprolifera- tive disorder can be confidently performed at this stage of the diagnostic workup.

A challenging issue is represented by B-cell splenic lymphomas in which CD5 is even partially expressed by the neoplastic clone as part of an aberrant phenotype not fulfilling the criteria for chronic lymphocytic leukemia and MCL diagnosis because the differential diagnosis of these cases includes CD5 ${ }^{+}$SMZL, SL-u cases, CD5 ${ }^{+}$ LPL cases, and atypical chronic lymphocytic leukemia and MCL cases. ${ }^{36,38,40,41}$ In these cases, in situ hybridization for CCND1/ immunoglobulin $\mathrm{H}(\mathrm{IgH})$ gene fusion should be consistently tested, and any attempt at subclassification should be deferred until 
Table 4. SL entities

\begin{tabular}{|c|c|c|c|c|c|c|c|c|c|c|c|c|}
\hline \multirow[b]{2}{*}{ B-cell } & \multicolumn{12}{|c|}{ Flow cytometry immunophenotype } \\
\hline & $\kappa \lambda>4$ or $<0.5$ & slg; clg & CD20 & CD5 & CD10 & CD23 & FMC7 & CD11c & CD25 & CD103 & CD38 & Cyclin-D1 \\
\hline SMZL & + & $+;-1+$ & + & $-1+$ & - & $-1+$ & + & $+1-$ & $-1+$ & - & $-1+$ & - \\
\hline \multicolumn{13}{|l|}{ SLL-u } \\
\hline SDRPBCL & + & $+/-;-$ & + & $-1+$ & - & - & + & + & - & $-1+$ & - & - \\
\hline $\mathrm{HCL}-\mathrm{v}$ & + & $+;-$ & + & - & - & - & + & + & - & + & NA & NA \\
\hline $\mathrm{HCL}$ & + & $+;-$ & + & - & - & - & + & + & + & + & NA & $+1-$ \\
\hline LPL & + & $+/-;+$ & + & $-1+$ & $-1+$ & $-1+$ & + & - & + & - & + & - \\
\hline B-PLL & + & + & + & $-1+$ & - & $-1+$ & + & + & - & - & $+1-$ & - \\
\hline $\mathrm{MCL}^{*}$ & + & $+;-$ & + & + & - & - & + & - & $-1+$ & - & $-1+$ & + \\
\hline $\mathrm{FL}^{*}$ & + & $+;-$ & + & - & $+1-$ & $-1+$ & + & - & - & - & NA & - \\
\hline DLBCL* & $+1-$ & $+1-;-1+$ & + & - & $+1-$ & - & + & NA & - & NA & - & - \\
\hline MTLBL* & $+1-$ & $+1-;-1+$ & + & - & - & - & NA & NA & NA & NA & - & - \\
\hline T-cell & $\mathrm{TCR} \alpha \boldsymbol{\beta}$ & TCR $\gamma \delta$ & CD2 & CD3 & CD5 & CD7 & CD4 & CD8 & CD25 & CD16 & CD56 & CD57 \\
\hline T-LGL & + & - & + & + & $-1+$ & $-1+$ & - & + & - & + & - & + \\
\hline HSTL & - & + & + & + & - & + & - & $-1+$ & - & - & $+1-$ & - \\
\hline
\end{tabular}

$\kappa \lambda$ indicates к-to- $\lambda$ light chain ratio; slg, surface immunoglobulin; clg cytoplasmatic immunoglobulin; CD, cluster of differentiation; NA, not applicable; TCR, T-cell receptor; SDRPBCL, splenic diffuse red pulp B-cell lymphoma; HCL-v, hairy cell leukemia variant; and MTLBL, micronodular T-cell rich histiocyte-rich diffuse large B-cell lymphoma.

+ indicates usually positive (ie, $\sim 90 \%$ of cases or more are positive); - , usually negative; and $+/-$ and $-/+$ may be positive or negative (the first sign indicating the more frequent condition)

*Primary splenic form.

cytogenetic, biomolecular, and histopathologic data are available. The finding of CD10 marker expression on a circulating light-chain restricted mature B-cell population is suggestive of germinal center-derived lymphomas but does not permit differentiation between follicular (FL) and diffuse large B-cell lymphomas (DLBCLs), whose definite diagnosis relies on histopathologic and molecular clues. ${ }^{42}$ Finally, the existence of several diagnostic pitfalls, such as MCL with partial or absent CD5 expression, CD10- FL, and clonal B-cell populations lacking clear-cut lightchain restriction, suggests a note of caution about relying exclusively on flow cytometry for rendering a diagnosis. ${ }^{38,42}$

\section{BM evaluation}

In SLs, the BM is almost constantly involved, even when the leukemic component is inconspicuous. Therefore, the BM represents the most easily accessible tissue for the histopathologic analysis. At the same time, it is an invaluable source of fresh cells for immunophenotypic, biomolecular, and cytogenetic characterization of the neoplastic clone. ${ }^{43}$ On these premises, we recommend to always perform both BM aspirate and trephine biopsy.

Some of the key features that can be determined on BM evaluation are highlighted in Table 5.

On BM histopathologic and immunohistochemical examination, a conclusive diagnosis can be reached in several lymphoid neoplasms presenting as SLs. These include HCL, T-LGL, and B-prolymphocytic leukemia, in which the BM evaluation represents the diagnostic "gold standard" according to the 2008 World Health Organization classification of tumors of hematopoietic and lymphoid tissues. ${ }^{44-46}$ Moreover, BM assessment makes it possible to reach an accurate diagnosis in most cases of MCL, HSTL, LPL, and SMZL, even in the absence of lymph node or spleen assessment. ${ }^{12,17,27,35}$

SLs of germinal center B-cell derivation may be difficult to classify in the BM because of the lack of germinal centerassociated phenotypic and cytogenetic/molecular markers, which has been reported in a considerable fraction of primary splenic FL cases. $^{22}$ In addition, diagnosis of micronodular T-cell/histiocyterich large B-cell lymphoma in the BM may prove challenging, given the puzzling effect of the rich and heterogeneous cloneassociated reactive environment. ${ }^{24}$

On BM colonization, most lymphomas/leukemias included in the category of SLs display a marked tropism for the BM vascular niche, which shares several features (eg, cellular composition and adhesion profile) with the splenic red pulp and liver sinusoidal vasculature. ${ }^{47}$ This is reflected by the tendency of neoplastic cells to lodge inside the BM sinusoids giving rise to a peculiar intrasinusoidal infiltration, which can be observed either alone or in combination with interstitial and/or nodular infiltrates (Figure 3A). ${ }^{48}$ Such an intrasinusoidal $\mathrm{BM}$ infiltration has been regarded as a hint to support the diagnosis of SMZL when in the context of an appropriate clinical picture, PB morphology, and immunophenotype. ${ }^{49}$ A prominent, almost exclusive, intrasinusoidal infiltration characterizes also the splenic diffuse red pulp small B-cell lymphoma and hairy cell leukemia-variant (Figure 3B), 2 largely overlapping splenic neoplasms, whose distinction from SMZL is mainly based on PB morphology and on immunophenotypic features, such as prevalent IgG usage and high DBA-44 expression. ${ }^{50,51}$ Along with SMZL and SL-u, an intrasinusoidal component is a common feature of T-LGL and HSTL BM infiltrates (Figure 3C-D). ${ }^{45,52}$

A confounding element in the interpretation of BM assessment of patients with suspected SL may be represented by the presence of chronic $\mathrm{HCV}$ infection. Actually, in $\mathrm{HCV}$-infected patients, scattered reactive lymphoid aggregates are commonly detected in the BM parenchyma. ${ }^{9}$ These lymphoid aggregates (usually accounting for up to $10 \%$ of the overall BM cellularity) display considerable overlap with neoplastic ones as far as morphology is concerned, being predominantly sited in the intertrabecular areas of the BM parenchyma and showing a nodular architecture with a variable degree of interstitial and/or intrasinusoidal spread. On immunohistochemistry, these aggregates display a mixed B and T cellular composition, yet they may be indistinguishable from the lymphomatous infiltrates of SLs lacking a diagnostic phenotypic signature, such as SMZL, SL-u, and LPL. For these reasons, we adopt particular caution in interpreting nonspecific BM lymphoid infiltrates when in the context of $\mathrm{HCV}$-infected patients with suspect SL; and whenever possible, we repeat BM assessment after 6 months from the first biopsy in the attempt of highlighting 
From www.bloodjournal.org by guest on November 14, 2016. For personal use only.

Table 5. Diagnostic key features that can be determined on BM evaluation in SLs

\begin{tabular}{|c|c|c|c|}
\hline $\begin{array}{l}\text { Disease } \\
\text { entity }\end{array}$ & Neoplastic cell morphology & Infiltration pattern & Additional diagnostic clues \\
\hline SMZL & $\begin{array}{l}\text { Small round lymphocytes and medium-sized cells with } \\
\text { dispersed chromatin and pale cytoplasm }\end{array}$ & $\begin{array}{l}\text { Intrasinusoidal with or without } \\
\text { interstitial and nodular } \\
\text { component }\end{array}$ & $\begin{array}{l}\text { del }(7 q) \text { in up to } 40 \% \text { of cases; surface } \operatorname{lgM} \text { and } \operatorname{lgD} \\
\text { expression }\end{array}$ \\
\hline \multicolumn{4}{|l|}{ SLL-u } \\
\hline SDRPBCL & $\begin{array}{l}\text { Small- to medium-sized lymphocytes similar to those of } \\
\text { SMZL }\end{array}$ & Intrasinusoidal & $\begin{array}{l}\text { Frequent IgG surface expression; strong DBA-44 } \\
\text { positivity }\end{array}$ \\
\hline HCL-v & $\begin{array}{l}\text { Medium-sized cells with oval or convoluted nuclei and } \\
\text { prominent central nucleoli resembling prolymphocytes }\end{array}$ & Intrasinusoidal & $\begin{array}{l}\text { Absence of significant reticulin fibrosis, annexin-A1 } \\
\text { negative constant lgG surface expression }\end{array}$ \\
\hline $\mathrm{HCL}$ & $\begin{array}{l}\text { Small- to medium-sized lymphocytes with oval or } \\
\text { indented nuclei, homogeneous chromatin and } \\
\text { abundant cytoplasm }\end{array}$ & Loose interstitial or patchy & $\begin{array}{l}\text { Specific annexin-A1 expression; increase in reticulin } \\
\text { fibers }\end{array}$ \\
\hline LPL & $\begin{array}{l}\text { Small lymphocytes admixed with plasmacytoid } \\
\text { lymphocytes and plasma cells }\end{array}$ & Nodular; interstitial or diffuse & $\begin{array}{l}\text { Cytoplasmic Ig expression (mostly lgM); } 6 \mathrm{q} \text { - in up to } 50 \% \\
\text { of BM-based cases; abundant mast cell infiltration }\end{array}$ \\
\hline B-PLL & $\begin{array}{l}\text { Medium-sized cell with round nucleus, moderately } \\
\text { condensed chromatin, and prominent nucleolus }\end{array}$ & Interstitial; nodular & del $(17 p)$ in $50 \%$ of cases \\
\hline MCL & $\begin{array}{l}\text { Small- to medium-sized lymphoid cells with slightly to } \\
\text { markedly irregular nuclei, dispersed chromatin, and } \\
\text { inconspicuous nucleoli; blastoid variant shows larger } \\
\text { cells resembling prolymphocytes }\end{array}$ & Dense interstitial; diffuse & $t(11 ; 14) / C C N D 1$ rearrangement \\
\hline $\mathrm{FL}$ & $\begin{array}{l}\text { Small lymphocytes with slightly irregular nuclei and } \\
\text { abundant pale cytoplasm. }\end{array}$ & Paratrabecular; nodular & $\begin{array}{l}\mathrm{t}(14 ; 18) / \mathrm{BCL} 2 \text { rearrangement; BCL2 and BCL6 IHC } \\
\text { expression }\end{array}$ \\
\hline DLBCL & $\begin{array}{l}\text { Neoplastic cells in the BM may be large or more } \\
\text { frequently medium-sized lymphocytes resembling } \\
\text { those of low-grade B cell lymphomas }\end{array}$ & Nodular; interstitial; diffuse & IRF4/MUM-1 IHC expression in up $65 \%$ of cases \\
\hline MTLBL & $\begin{array}{l}\text { Few scattered large B-cells intermingling with small } \mathrm{T} \text { and } \\
\text { B lymphocytes, and macrophages }\end{array}$ & Nodular; paratrabecular & \\
\hline T-LGL & $\begin{array}{l}\text { Large and granular lymphocytes with moderate to } \\
\text { abundant cytoplasm and azurophilic ganules }\end{array}$ & Intrasinusoidal and interstitial & $\mathrm{IHC}$ expression of TIA-1, granzyme-B, and granzyme-M \\
\hline HSTCL & $\begin{array}{l}\text { Monotonous medium-sized cells with round nuclei and a } \\
\text { rim of pale cytoplasm or atypical large cells with blastic } \\
\text { morphology }\end{array}$ & Intrasinusoidal & $\begin{array}{l}\text { Hyperplasia of the noninvolved marrow with or without } \\
\text { dysplastic features; hemophagocytic histiocytosis }\end{array}$ \\
\hline
\end{tabular}

CCND1 indicates cyclin D1; IHC, immunohistochemistry; SDRPBCL, splenic diffuse red pulp B-cell lymphoma; HCL-v, hairy cell leukemia variant; and MTLBL, micronodular T-cell rich histiocyte-rich diffuse large B-cell lymphoma.

relevant changes in the extent, pattern, and composition of the BM infiltrates that might suggest their neoplastic nature.

\section{Splenectomy: the (in)dispensable diagnostic procedure}

As a result of the thorough application of the aforementioned diagnostic workup integrating clinical and imaging data, and data from $\mathrm{PB}$ and $\mathrm{BM}$ investigations, most cases of lymphomas presenting as unexplained splenomegaly can be recognized as specific B- or T-cell lymphoma histotypes. However, in a minority of cases, the output of such a diagnostic workup can be that of a generic diagnosis of B-cell chronic lymphoproliferative disorder, or it can even leave the nature of the splenomegaly unsolved (Figure 1). In these conditions, spleen histology represents the only mean for reaching a conclusive diagnosis. However, even spleen histology is not free of diagnostic pitfalls, which lie in the possible occurrence of overlapping patterns of infiltration among different lymphoma entities and in the expression of aberrant immunophenotypes by neoplastic clones. ${ }^{53}$ Altogether, these pitfalls issue strong warning about considering diagnostic splenectomy as an easy shortcut to a prompt SL diagnosis. As in BM assessment, such pitfalls may represent a challenge, even for experienced hematopathologists, and can only be overcome through a consistent integration of clinical, biomolecular, and cytogenetic data.

We always resort to diagnostic splenectomy when neither PB examination nor $\mathrm{BM}$ assessment highlights the presence of a lymphoid neoplastic clone, which in our experience occurs in approximately $5 \%$ of SL cases. Similarly, we always perform splenectomy for diagnostic purposes when BM assessment triggers a differential diagnostic problem between splenic FL and large B-cell lymphoma, which would affect treatment choices and outcome expectations. ${ }^{54}$

By contrast, our approach to patients receiving a generic diagnosis of B-cell chronic lymphoproliferative disorder after PB and $\mathrm{BM}$ assessment is to avoid splenectomy as a mere diagnostic refinement. Given the indolent pace of the SLs commonly falling in this "basket diagnosis," namely, SMZL, SL-u, and LPL, allowing the adoption of a watchful waiting policy, ${ }^{36,55}$ we consider splenectomy only when it fully matches the need of a therapeutic intervention. However, even in this setting of patients, there are few exceptions in which a further diagnostic characterization through spleen histology is of strong clinical relevance. These include rare cases in which the suspect of a mantle cell lymphoma persists despite $\mathrm{PB}$ and $\mathrm{BM}$ investigations, ${ }^{40}$ and cases in which an underlying high-grade lymphoma (or high-grade transformation) is suspected on the basis of focal lesions on spleen imaging, B-symptoms, or laboratory findings (eg, high lactate dehydrogenase levels). ${ }^{56}$

Elective open splenectomy has rather low, yet sizeable (particularly among elderly patients), morbidity and mortality rates accounting for approximately $12 \%$ and less than $1 \%$, respectively ${ }^{57}$; these rates are even lower for laparoscopic splenectomy, which can also be safely performed in cases of massive splenomegaly. ${ }^{58}$ In this 


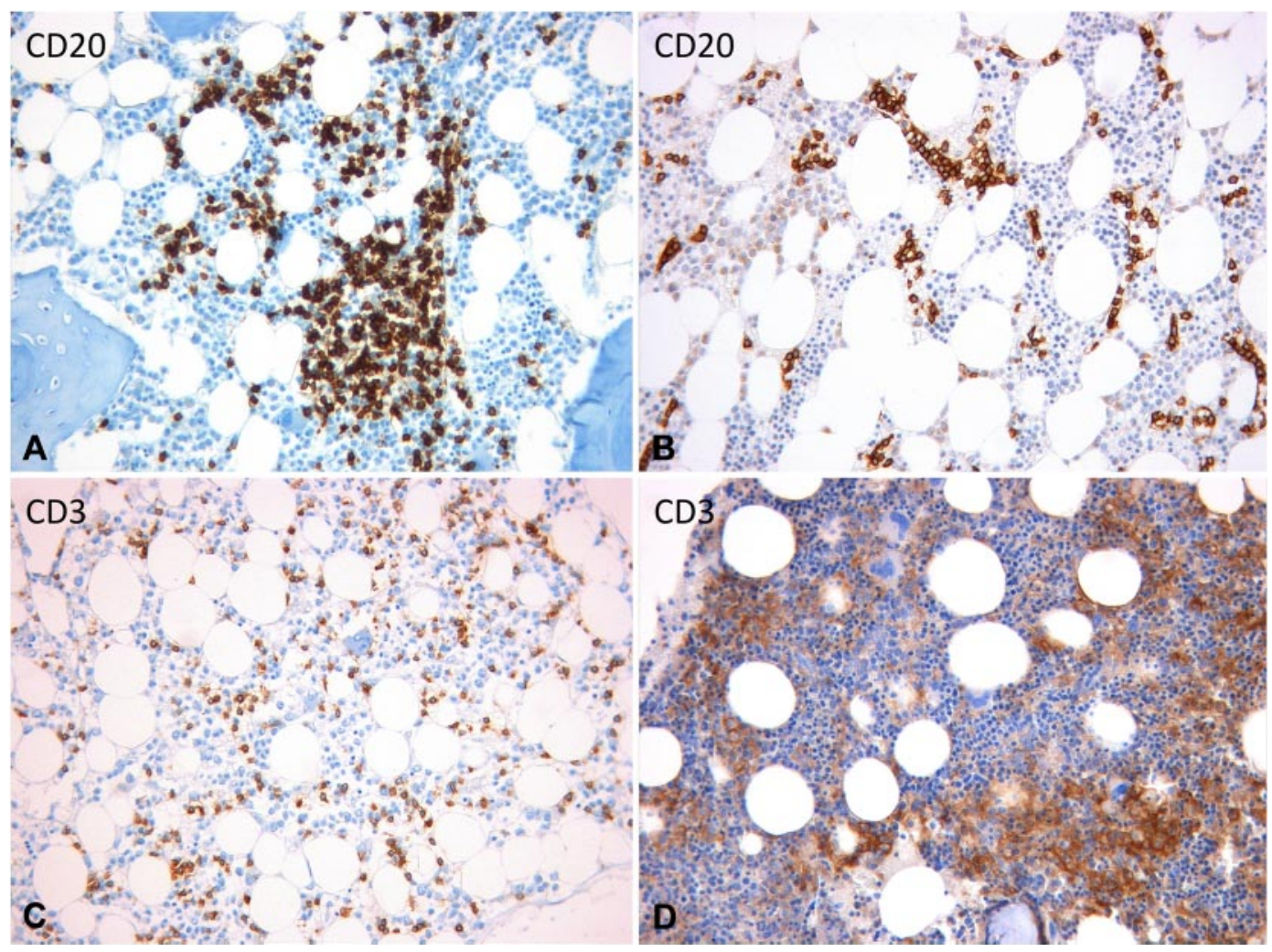

Figure 3. BM intrasinusoidal infiltration pattern in different SL entities. (A) SMZL: mixed nodular and intrasinusoidal infiltration. (B) SDRPSBCL: neoplastic cells are exclusively lodged inside the dilated sinusoids. (C) T-LGL: subtle intrasinusoidal and interstitial infiltration. (D) HSTL: highly atypical large neoplastic cells engulf the BM sinusoids. (A-B) Anti-CD20 immunostaining using the streptavidin-biotin-peroxidase complex and 3-3'-diaminobenzidine (brown signal). (C-D) Anti-CD3 immunostaining using the streptavidin-biotin-peroxidase complex and 3-3'-diaminobenzidine (brown signal). (A-D) Original magnification $\times 200$. Images were captured by a Leica DM 3000 optical microscope, Leica DFC 320 digital camera, and Leica IM50 software.

latter procedure, implying the fragmentation of the splenic parenchyma, a higher degree of caution is required to avoid excessive distortion of samples during removal, which may flaw histopathologic assessment.

Alternate options to splenectomy for diagnostic purposes are represented by echo-guided spleen biopsy and fine needle aspiration which, especially in the setting of peripheral splenic focal lesions, have purportedly been shown to have good diagnostic accuracy and low morbidity. ${ }^{59}$ Anyway, we do not perform these procedures as part of the routine diagnostic workup of SLs.

\section{Treatment strategies in SLs}

Despite a shared presentation and clinical findings showing considerable overlap, SLs have little in common as far as the therapeutic strategies are concerned. A first "gross" distinction can be operated between rare splenic forms of lymphomas that usually arise in lymph nodes, such as FL, MCL, and DLBCLs, and lymphomas/ leukemias in which the splenic presentation (and BM involvement) is frequent or even typical (eg, SMZL, T-LGL; Table 1).

Lymphomas belonging to the first of the aforementioned categories may either maintain a common biologic and clinical behavior when presenting as SLs, which supports the adoption of the same therapeutic strategies used in their nodal counterparts, or may display a frankly different behavior justifying ad-hoc therapeutic interventions. In the treatment of these latter splenic "variants," the main limit is represented by the lack of standard treatment because most of the therapeutic approaches so far reported mainly derive from small retrospective series or anecdotic reports.
From the 2 reports so far published in the literature gathering cases of primary splenic FL, a rather heterogeneous picture has emerged as far as the biology of this SL is concerned. Actually, most of the cases of primary splenic FL reported by Mollejo et al were characterized by BCL2 and/or CD10 negativity ( 8 of 9 cases and 4 of 9 cases, respectively) and by the absence of BCL2 translocation ( 8 of 8 cases), as well as by a high proliferation index ( 7 of 9 cases) and rate of transformation toward DLBCL ( 3 of 8 cases). ${ }^{22}$ Conversely, all the cases of splenic FL reported by Howard et al displayed biologic features paralleling those of nodal FL cases. ${ }^{60}$ All cases of primary splenic FL included in these 2 reports underwent diagnostic splenectomy, which was followed by either watchful waiting or systemic therapy ranging from anthracycline-based therapy to stem cell transplantation, with rituximab being administered in only 3 patients as monotherapy. At present, there is not enough evidence of a diverse biologic and clinical behavior of primary splenic FLs to support the adoption of treatment strategies diverging from those of nodal FLs. For this reason, the association of rituximab and polychemotherapy, whether or not preceded by splenectomy, can be considered as the most appropriate treatment for this setting of patients. ${ }^{61}$

The issue of treating MCL has been thoroughly discussed in a recent article of this "How I Treat" series. ${ }^{62}$ In the splenic forms of MCL, the neoplastic clone commonly shows an overt leukemic dissemination and $\mathrm{BM}$ involvement and harbors a mutated $\mathrm{Ig}$ repertoire with a higher frequency than nodal MCLs do. ${ }^{63}$ Splenectomy has demonstrated impressive and durable responses in splenic MCLs, producing a significant reduction of the circulating leukemic component along with an effective recovery from cytopenia. ${ }^{64}$ Whether this seemingly indolent clinical behavior observed after 
splenectomy is expression of a peculiar biology of the neoplastic clone or a consequence of the massive tumor debulking provided by spleen removal is not clear. Even if endorsed with a high therapeutic efficacy, splenectomy should be regarded as a palliative treatment, whose main limit lies in the persistence of a BM neoplastic cell reservoir. Therefore, our approach to splenic MCL patients is that of performing splenectomy as first-line treatment and then pursuing the attainment of a complete remission through chemo-immunotherapy administration in all the eligible patients, including those who experienced a complete hematologic response to splenectomy. Specifically, we adopt rituximab + cyclophosphamide, vincristine, doxorubicin, prednisone $(\mathrm{R}-\mathrm{CHOP}) \mathrm{q} 21 \times$ 3 alternating with rituximab + high-dose cytarabine 2 times. ${ }^{65}$

DLBCLs of the spleen behave as aggressive neoplasms as those arising in lymph nodes and other extranodal sites do. Hence, treatment of these SLs should be guided by the same general recommendations proposed for DLBCLs. ${ }^{66}$ In the rare patients presenting with DLBCL confined to the spleen, who are splenectomized for diagnosis, we follow the same strategy that we adopt for DLBCL patients with surgically resected localized extranodal disease and that involves the use of CHOP plus rituximab for 4 cycles. In all other cases of splenic DLBCL in which BM histology and/or imaging demonstrate disease spread outside the spleen, we perform restaging after 4 cycles of R-CHOP, with the intention to treat patients 2 cycles past complete remission achievement. Different from splenic DLBCL/not otherwise specified, the splenic form of the micronodular T-cell/histiocyte-rich DLBCL subtype presents with a micronodular infiltration of the spleen and the disease almost invariably involves the BM or other extranodal sites. Most of the cases so far reported in the literature have shown a rather dismal prognosis, with few recent exceptions of cases treated with R-CHOP therapy. ${ }^{67}$ So far, our limited experience with splenic T-cell/histiocyte-rich DLBCL patients does not allow for personal indications for the treatment of this rare lymphoma subtype.

As far as malignancies commonly or typically presenting themselves as SLs are concerned, the therapeutic approach to HCL and LPL has been detailed in 2 recent articles from the "How I Treat" collection and therefore will not be discussed herein. ${ }^{55,68}$

B-cell prolymphocytic leukemia (B-PLL) is an aggressive lymphoid malignancy whose poor response to treatment is in line with the frequent occurrence of p53 mutation in the neoplastic clone. The response rates so far obtained with a broad range of treatments, including alkylating agents, combination chemotherapy (CHOP), and purine analogs (pentostatin, fludarabine, and cladribine), range from $30 \%$ to $60 \%$, with very few complete responders $(\mathrm{CRs} ;<20 \%)$ and an overall median survival rarely exceeding 3 years. ${ }^{69}$ The experience with monoclonal antibody-based immunotherapy in B-PLL is confined to few cases treated with alemtuzumab or rituximab. ${ }^{70}$ The attainment of durable CRs in the few reported cases of pretreated B-PLL patients undergoing rituximab therapy, along with the high expression of the CD20 target antigen on B-PLL cells, make the use of rituximab in combination with chemotherapy a sound option..$^{71}$ In our experience, the main hurdle in treating B-PLL patients consists of the advanced age and low performance status of these frail subjects. Some of these patients can be effectively, though temporarily, palliated through splenectomy or splenic irradiation, which can produce a control over the disease inducing the recovery of peripheral cytopenia, improvement of the performance status, and even a considerable reduction of lymphocytosis. ${ }^{70}$ Taking into account the invariably fatal course of this disease, the adoption of allogeneic stem cell transplantation should be considered on diagnosis in the rare young patients.

HSTL is a very rare lymphoma mainly affecting young men in their second or third decade of life, who are commonly heavily symptomatic because of cytopenia and huge hepatosplenomegaly. In this extremely aggressive lymphoma showing a dismal prognosis with a median overall survival less than 2 years and poor response to standard chemotherapy, we warrant the use of highdose cytarabine plus platinum-containing induction chemotherapy consolidated with stem cell transplantation. ${ }^{12}$ In patients who are not eligible for a transplantation procedure, a transient control over the neoplastic clone outgrowth may be achieved by anthracyclinecontaining chemotherapy, purine analogs, and/or alemtuzumab immunotherapy. Splenectomy has little, if any, role in HSTL patients because its efficacy in ameliorating peripheral cytopenia may be flawed by the rather frequent occurrence of hemophagocytic histiocytosis in the BM.

As most other lymphoproliferative disorders falling in the "basket" category of SLs, T-LGL lacks a standardized treatment. The commonly indolent nature of this lymphoproliferative disorder, which in some cases may even border on a benign expansion of cytotoxic T cells, candidates most patients to a watchful waiting policy. ${ }^{72}$ We base the decision of starting treatment on the appearance of signs and/or symptoms related to cytopenia. The first-line therapy encompasses weekly low-dose methotrexate, daily low-dose cyclosporine, or cyclophosphamide. ${ }^{72,73}$ Responses to these treatments may require up to 3 months before becoming clinically appreciable, and preservation of a "responder" status requires continued maintenance therapy. Although these treatments seem to be equally effective in inducing complete or partial responses in a considerable percentage of patients (50\%-80\%), our preference is for low-dose methotrexate $\left(5-10 \mathrm{mg} / \mathrm{m}^{2}\right)$ as in our experience this drug proved to be manageable and well tolerated. Because these immunosuppressant-based treatments barely affect the tumor burden despite PB count amelioration, other options such as purine analogs might be envisaged, especially in younger patients. Indeed, purine analogs have been reported to produce clinical responses in $40 \%$ to $60 \%$ of patients, lasting several months after treatment discontinuation. ${ }^{72}$

In our clinical practice, nearly $80 \%$ of patients presenting with a suspect SL are diagnosed with SMZL or SL-u. These lymphoid malignancies, mainly occurring in the elderly, commonly pursue a truly indolent course with approximately $70 \%$ of patients alive at 10 years from the diagnosis and nearly $30 \%$ of patients eventually dying of causes unrelated with the lymphoma. ${ }^{74}$ Approximately one-third of patients can be conveniently managed with a watchful waiting policy for several years. However, a sizeable subgroup of patients may display a progressive disease with a less favorable outcome (56\% of patients alive at 5 years). ${ }^{27,36}$ At present, there is no indication that early treatment is able to affect the natural course of these diseases; thus, decision-making about treatment in the clinical practice should be based on symptoms and clinical features. Actually, one notable exception to this rule of thumb is represented by the presence of HCV infection, which, already on presentation, candidate patients to receive antiviral therapy with pegylated interferon- $\alpha$ and ribavirin. In $\mathrm{HCV}^{+}$SMZL patients achieving clearance of HCV RNA after antiviral treatment, the sustained virologic response has been reported to be paralleled by the clinical remission of the lymphoproliferative disease in $75 \%$ of cases. ${ }^{75,76}$ So far, we have treated $5 \mathrm{HCV}^{+}$SMZL patients with pegylated interferon and ribavirin observing no responses; nonetheless, we still consider such an antiviral therapy approach sound and 
Table 6. SMZL IIL prognostic score

Risk factors
$\mathrm{Hb}<12 \mathrm{~g} / \mathrm{dL}$
$\mathrm{LDH}$ level higher than normal
Albumin level $<3.5 \mathrm{~g} / \mathrm{dL}$
Score classes
Low risk: no risk factors ( $83 \% 5$-year OS*)
Intermediate risk: 1 risk factor $\left(72 \% 5\right.$-year OS $\left.{ }^{\star}\right)$
High risk: 2 or more risk factors $(56 \% 5$-year OS $)$

IIL indicates Intergruppo Italiano Linfomi; Hb, hemoglobin; LDH, lactate dehydrogenase; and OS, overall survival.

${ }^{*} 95 \%$ confidence interval.

the attainment of HCV clearance a major clinical goal to be pursued early in all HCV-infected SMZL patients.

We allocate presenting patients in different risk categories according to the Intergruppo Italiano Linfomi prognostic score system (Table 6). ${ }^{74}$ We follow up low-risk patients every 4 months for history, physical examination, laboratory tests, and blood counts with the aim of assessing disease steadiness. Once a stable clinical course has been verified, less frequent follow-up is adopted. Specifically, patients in whom the prognostic score and the spleen size remain unchanged are followed-up every 6 months without treatment, whereas those showing a switch in the prognos- tic score and/or an increase in spleen size of at least $20 \%$ are followed-up every 2 months. Similarly, in asymptomatic patients who score as intermediate or high risk on presentation, we adopt a watchful waiting policy with a 2-month follow-up and with the prospect of starting treatment on clinical symptoms appearance. Any alteration to this "waiting move" tactic will depend on the definite demonstration of an improved survival from early institution of treatment based on upfront prognostic stratification. Notably, the core part of the "waiting move" lies in open communication with the patient aiming to render her/him fully aware about the natural course of her/his disease and about the subtle, yet crucial, demarcation existing between "waiting" and "not taking care."

The key steps of our treatment approach for the management of previously untreated SMZL/SL-u patients are sketched out in Figure 4.

The clinical signs and symptoms that most frequently trigger our decision to undertake treatment are the development of marked anemia $(\mathrm{Hb}<10 \mathrm{~g} / \mathrm{dL})$, abdominal uneasiness and left flank pain secondary to huge splenomegaly, and constitutional symptoms. Thrombocytopenia is only rarely severe and commonly does not imply an increased hemorrhagic risk $^{36}$; therefore, we usually defer treatment of SMZL/SL-u patients with isolated thrombocytopenia until a drop in platelets to $80 \times 10^{9} / \mathrm{L}$ is observed.

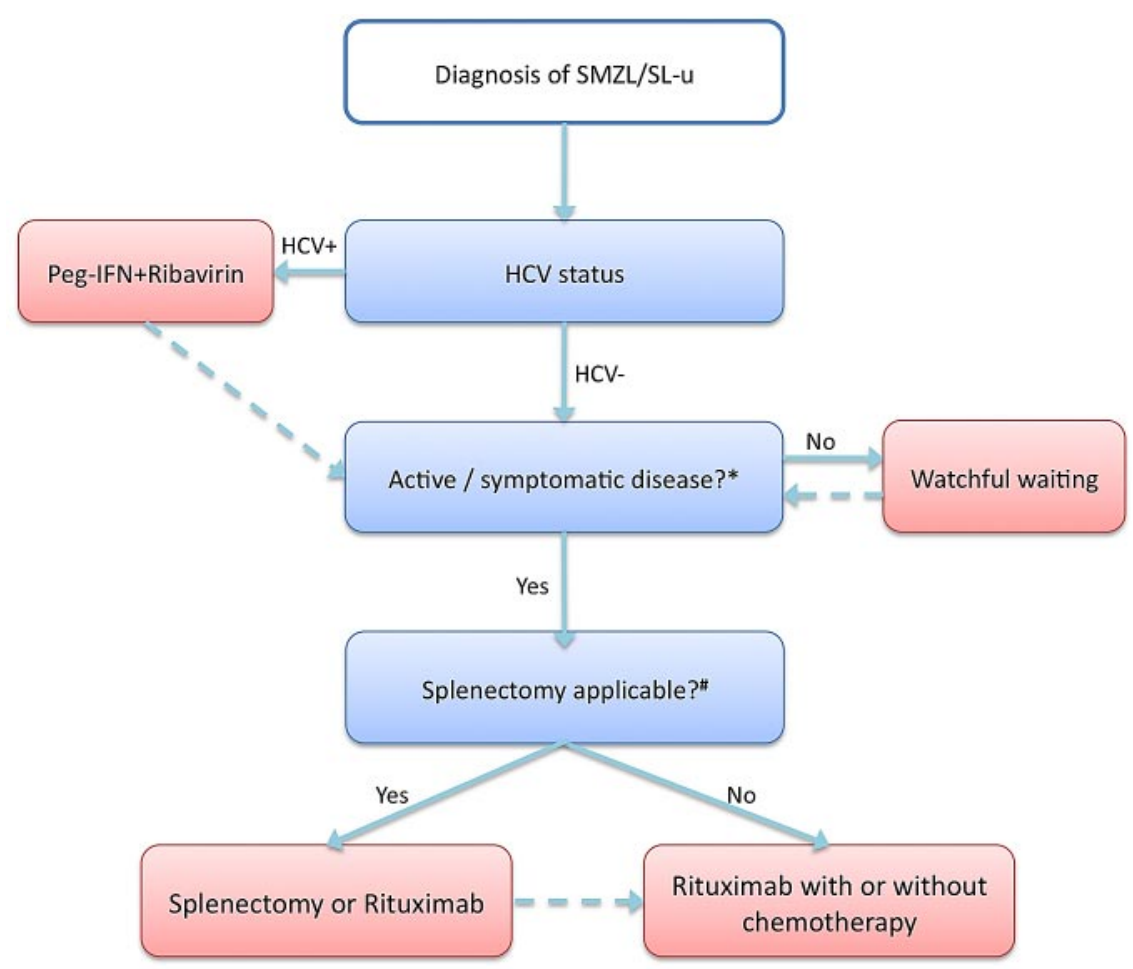

${ }^{*} \mathrm{Hb}<10 \mathrm{~g} / \mathrm{dl} ; \mathrm{LDH}>\mathrm{N} ; \mathrm{PLT} \leq 80 \times 10^{9} / \mathrm{L}$; rapidly raising lymphocyte count; abdominal discomfort; abdominal lymph nodes and/or extranodal involvement.

\# Splenectomy should be considered not applicable if at least one of the following conditions occurs:

- Patient unwilling to undergo to / unfit for surgery

- Rapidly raising lymphocyte count

- Abdominal lymph nodes and/or extranodal involvement

- AHA or other autoimmune disorders 
Effective recovery from cytopenia- and splenomegaly-related symptoms is promptly obtained through splenectomy, which, in most patients, may assure a long window period free of symptoms. During this period, the disease persists in the BM and PB and will eventually progress in a median time of 4 to 5 years. ${ }^{77}$ On these bases, such a palliative treatment is regarded as the first choice therapy in SMZL/SL-u, when a treatment is needed. For patients who progress after splenectomy, as well as for those who are unfit for splenectomy or unwilling to undergo surgery, systemic treatment may be appropriate. However, which patients would benefit most of such systemic therapy, which one would be the most effective drug combination, and when treatment should be started during the natural course of the disease, all remain open and debated issues. ${ }^{36}$ A good control over the disease, and even complete responses, can be achieved in naive (ie, not splenectomized) and relapsed patients through therapy with purine analogs $(\sim 20 \% \mathrm{CR})$ and immunotherapy with rituximab either alone or in combination with chemotherapy $(\sim 40 \%$ and $60 \% \mathrm{CR}$, respectively) ${ }^{78-81}$ In our opinion, the remarkable response rates and low toxicity so far observed with rituximab make this therapeutic option strong enough to challenge the primacy of splenectomy as the first-line treatment of choice. In our practice, we use rituximab as monotherapy ( $375 \mathrm{mg} / \mathrm{m}^{2}$ weekly 4 to 6 times) in the first-line treatment of frail patients and of patients with concurrent autoimmune manifestations in light of its low toxicity profile, although we generally resort to the combination of rituximab and purine analogs (R-cladribine, R-fludarabine) or rituximab and cyclophosphamide, vincristine, myocet, and prednisone (R-COMP) for fit patients with disseminated disease to nodal and extranodal sites other than the spleen, and for patients with constitutional symptoms and/or signs of high-grade transformation. ${ }^{82}$

Recently, bendamustine has emerged as a highly versatile drug characterized by a peculiar mechanism of action, mild (mainly hematologic) toxicity, and a broad spectrum of activity encompassing almost all the mature B-cell neoplasms, including marginal zone lymphomas. ${ }^{83,84}$ In line with this evidence, we have started offering the association of rituximab plus bendamustine as a second-line therapy option in relapsed or progressed patients. All the 6 SMZL patients we have so far treated with rituximab plus bendamustine have responded to this therapy, 4 of 6 obtained a CR and, notably, none of the patients achieving a CR was splenectomized. Altogether, the promising responses and the low toxicity profile observed make the association of rituximab and bendamustine worth investigating in specifically designed prospective trials.

In conclusion, while detailing how we diagnose and treat splenic lymphomas, we went through the numerous open issues that still cast their shadows over this group of malignancies and evoke Alexander Pope's description of "strange phantoms" lurking in the "gloomy cave of Spleen." 85 Together, all these issues represent a strong appeal for future cooperative efforts aimed to obtain a deeper understanding of the biology of these disorders and to prospectively investigate the efficacy of treatments, allowing the switch from an experience-based to an evidence-based approach.

\section{Authorship}

Contribution: E.I. and C.T. wrote the manuscript.

Conflict-of-interest disclosure: The authors declare no competing financial interests.

Correspondence: Emilio Iannitto, Department of Oncology, Haematology Unit, University of Palermo School of Medicine, Via del Vespro 129, 90127, Palermo, Italy; e-mail: emilio. iannitto@gmail.com.

\section{References}

1. Das Gupta T, Coombes B, Brasfeld RD. Primary malignant neoplasms of the spleen. Surg Gynecol Obstet. 1969;120:947-960.

2. Gobbi PG, Grignani GE, Pozzetti U, et al. Primary splenic lymphoma: does it exist? Haematologica. 1994;79(3):286-293.

3. Isaacson PG. Primary splenic lymphoma. Cancer Surv. 1997;30:193-212.

4. Swerdlow SH, Campo E, Harris NL, et al. WHO Classification of Tumours of Haematopoietic and Lymphoid Tissues. Lyon, France: IARC; 2008

5. Pozo AL, Godfrey EM, Bowles KM. Splenomegaly: investigation, diagnosis and management. Blood Rev. 2009;23(3):105-111.

6. Kraus MD, Fleming MD, Vonderheide RH. The spleen as a diagnostic specimen: a review of 10 years' experience at two tertiary care institutions. Cancer. 2001;91(11):2001-2009.

7. Carr JA, Shuarafa M, Velanovich V. Surgical indications in idiopathic splenomegaly. Arch Surg. 2002;137(1):64-68.

8. Pottakkat B, Kashyap R, Kumar A, Sikora SS, Saxena R, Kapoor VK. Redefining the role of splenectomy in patients with idiopathic splenomegaly. Aust NZJ Surg. 2006;76(8):679-682.

9. Klco JM, Geng B, Brunt EM, et al. Bone marrow biopsy in patients with hepatitis $C$ virus infection spectrum of findings and diagnostic utility. $A m \mathrm{~J}$ Hematol. 2010;85(2):106-110.

10. Mele A, Pulsoni A, Bianco E, et al. Hepatitis C virus and $B$-cell non-Hodgkin lymphomas: an Italian multicenter case-control study. Blood. 2003; 102(3):996-999.

11. Goldin LR, Landgren O. Autoimmunity and lym- phomagenesis. Int J Cancer. 2009;124(7):14971502.

12. Tripodo C, lannitto E, Florena AM, et al. Gammadelta T-cell lymphomas. Nat Rev Clin Oncol. 2009;6(12):707-717.

13. Franco V, Florena AM, Iannitto E. Splenic marginal zone lymphoma. Blood. 2003;101(7):24642472.

14. Traverse-Glehen A, Baseggio L, Bauchu EC, et al. Splenic red pulp lymphoma with numerous basophilic villous lymphocytes: a distinct clinicopathologic and molecular entity? Blood. 2008; 111(4):2253-2260.

15. Matutes E, Wotherspoon A, Catovsky D. The variant form of hairy-cell leukaemia. Best Pract Res Clin Haematol. 2003;16(1):41-56.

16. Hoffman MA. Clinical presentations and complications of hairy cell leukemia. Hematol Oncol Clin North Am. 2006;20(5):1065-1073.

17. Owen RG, Treon SP, Al-Katib A, et al. Clinicopathological definition of Waldenstrom's macroglobulinemia: consensus panel recommendations from the Second International Workshop on Waldenstrom's Macroglobulinemia. Semin Oncol. 2003;30(2):110-115.

18. Krishnan B, Matutes E, Dearden C. Prolymphocytic leukemias. Semin Oncol. 2006;33(2):257-263.

19. O'Malley DP. T-cell large granular leukemia and related proliferations. Am J Clin Pathol. 2007; 127(6):850-859.

20. Belhadj K, Reyes F, Farcet JP, et al. Hepatosplenic gammadelta $\mathrm{T}$-cell lymphoma is a rare clinicopathologic entity with poor outcome: report on a series of 21 patients. Blood. 2003;102(13): 4261-4269.
21. Angelopoulou MK, Siakantariz MP, Vassilakopoulos TP, et al. The splenic form of mantle cell lymphoma. Eur J Haematol. 2002;68(1):12-21.

22. Mollejo M, Rodriguez-Pinilla MS, Montes-Moreno $\mathrm{S}$, et al. Splenic follicular lymphoma: clinicopathologic characteristics of a series of 32 cases. Am J Surg Pathol. 2009;33(5):730-738.

23. Takeshita M, Sakai H, Okamura S, et al. Splenic large B-cell lymphoma in patients with hepatitis C virus infection. Hum Pathol. 2005;36(8):878-885.

24. Dogan A, Burke JS, Goteri G, Stitson RN, Wotherspoon AC, Isaacson PG. Micronodular T-cell/histiocyte-rich large B-cell lymphoma of the spleen: histology, immunophenotype, and differential diagnosis. Am J Surg Pathol. 2003;27(7): 903-911.

25. Gobbi PG, Broglia C, Carnevale Maffe G, Ruga A, Molinari E, Ascari E. Lymphomatous superficial lymph nodes: limitations of physical examination for accurate staging and response assessment. Haematologica. 2002;87(11):1151-1156.

26. Matutes E, Wotherspoon A, Catovsky D. Differential diagnosis in chronic lymphocytic leukaemia. Best Pract Res Clin Haematol. 2007;20(3):367384.

27. Iannitto E, Ambrosetti A, Ammatuna E, et al. Splenic marginal zone lymphoma with or without villous lymphocytes: hematologic findings and outcomes in a series of 57 patients. Cancer. 2004; 101(9):2050-2057

28. Arcaini L, Burcheri S, Rossi A, et al. Prevalence of $\mathrm{HCV}$ infection in nongastric marginal zone $\mathrm{B}$ cell lymphoma of MALT. Ann Oncol. 2007;18(2): 346-350.

29. Lamb PM, Lund A, Kanagasabay RR, Martin A, 
Webb JA, Reznek RH. Spleen size: how well do linear ultrasound measurements correlate with three-dimensional CT volume assessments? $\mathrm{Br} \mathrm{J}$ Radiol. 2002;75(895):573-577.

30. Gorg C, Weide R, Schwerk WB. Malignant splenic lymphoma: sonographic patterns, diagnosis and follow-up. Clin Radiol. 1997;52(7):535-540.

31. Gorg C, Faoro C, Bert T, Tebbe J, Neesse A, Wilhelm C. Contrast enhanced ultrasound of splenic lymphoma involvement. Eur J Radiol. [Epub ahead of print].

32. Peddu P, Shah M, Sidhu PS. Splenic abnormalities: a comparative review of ultrasound, microbubble-enhanced ultrasound and computed tomography. Clin Radiol. 2004;59(9):777-792.

33. Rutherford SC, Andemariam B, Philips SM, et al. FDG-PET in prediction of splenectomy findings in patients with known or suspected lymphoma. Leuk Lymphoma. 2008;49(4):719-726.

34. Elsayes KM, Narra VR, Mukundan G, Lewis JS Jr, Menias CO, Heiken JP. MR imaging of the spleen: spectrum of abnormalities. Radiographics. 2005;25(4):967-982.

35. Matutes E, Parry-Jones N, Brito-Babapulle V, et al. The leukemic presentation of mantle-cell lymphoma: disease features and prognostic factors in 58 patients. Leuk Lymphoma. 2004;45(10): 2007-2015.

36. Matutes E, Oscier D, Montalban C, et al. Splenic marginal zone lymphoma proposals for a revision of diagnostic, staging and therapeutic criteria. Leukemia. 2008;22(2):487-495.

37. Verbunt RJ, den Ottolander GJ, Kluin PM, Brederoo P, Kluin-Nelemans HC. Circulating buttock cells in non-Hodgkin's lymphoma. Leukemia. 1989;3(8):578-584.

38. Morice WG, Kurtin PJ, Hodnefield JM, et al. Predictive value of blood and bone marrow flow cytometry in B-cell lymphoma classification: comparative analysis of flow cytometry and tissue biopsy in 252 patients. Mayo Clin Proc. 2008; 83(7):776-785.

39. Dong HY, Weisberger J, Liu Z, Tugulea S. Immunophenotypic analysis of CD103+ B-lymphoproliferative disorders: hairy cell leukemia and its mimics. Am J Clin Pathol. 2009;131(4):586-595.

40. Baseggio L, Traverse-Glehen A, Petinataud F, et al. CD5 expression identifies a subset of splenic marginal zone lymphomas with higher lymphocytosis: a clinico-pathological, cytogenetic and molecular study of 24 cases. Haematologica. 2010 95(4):604-612.

41. Jevremovic D, Dronca RS, Morice WG, et al. CD5+ B-cell lymphoproliferative disorders: beyond chronic lymphocytic leukemia and mantle cell lymphoma. Leuk Res. 2010;34(9):1235-1238.

42. Dogan A, Du MQ, Aiello A, et al. Follicular lymphomas contain a clonally linked but phenotypically distinct neoplastic B-cell population in the interfollicular zone. Blood. 1998;91(12):4708-4714.

43. Wilkins BS, Clark DM. Making the most of bone marrow trephine biopsy. Histopathology. 2009; 55(6):631-640.

44. Foucar K, Falini B, Catovsky D, Stein H. Hairy cell leukemia. In: Swerdlow S, Campo E, Harris NL, et al, eds. WHO Classification of Tumours of Haematopoietic and Lymphoid Tissues. Lyon, France: IARC; 2008:188-190.

45. Chan WC, Foucar K, Morice WG, Catovsky D. T-cell large granular lymphocytic leukemia. In: Swerdlow S, Campo E, Harris NL, et al, eds. WHO Classification of Tumours of Haematopoietic and Lymphoid Tissues. Lyon, France: IARC; 2008:272-273.

46. Campo E, Catovsky D, Montserrat E, MullerHermelink HK, Harris NL, Stein H. B-cell prolymphocytic leukemia. In: Swerdlow S, Campo E, Harris NL, et al, eds. WHO Classification of Tumours of Haematopoietic and Lymphoid Tissues. Lyon, France: IARC; 2008:183-184.

47. Florena AM, Tripodo C, Porcasi R, et al. Immuno- phenotypic profile and role of adhesion molecules in splenic marginal zone lymphoma with bone marrow involvement. Leuk Lymphoma. 2006; 47(1):49-57.

48. Costes V, Duchayne E, Taib J, et al. Intrasinusoidal bone marrow infiltration: a common growth pattern for different lymphoma subtypes. $\mathrm{Br} \mathrm{J}$ Haematol. 2002;119(4):916-922.

49. Franco V, Florena AM, Campesi G. Intrasinusoidal bone marrow infiltration: a possible hallmark of splenic lymphoma. Histopathology. 1996;29(6): 571-575.

50. Piris M, Foucar K, Mollejo M, Campo E, Falini B. Splenic lymphoma/leukemia, unclassifiable. In: Swerdlow S, Campo E, Harris NL, et al, eds. WHO Classification of Tumours of Haematopoietic and Lymphoid Tissues. Lyon, France: IARC; 2008:191-193.

51. Traverse-Glehen A, Baseggio L, Callet-Bauchu E, et al. Hairy cell leukaemia-variant and splenic red pulp lymphoma: a single entity? Br J Haematol. 2010;150(1):113-116.

52. Gaulard P, Jaffe ES, Krenacs L, Macon WR. Hepatosplenic T-cell lymphoma. In: Swerdlow S, Campo E, Harris NL, et al, eds. WHO Classification of Tumours of Haematopoietic and Lymphoid Tissues. Lyon, France: IARC; 2008:292-293.

53. Piris MA, Mollejo M, Campo E, Menarguez J, Flores $\mathrm{T}$, Isaacson PG. A marginal zone pattern may be found in different varieties of non-Hodgkin's lymphoma: the morphology and immunohistology of splenic involvement by B-cell lymphomas simulating splenic marginal zone lymphoma. Histopathology. 1998;33(3):230-239.

54. van der Walt JD. Lymphomas in the bone marrow. Diagn Histopathol. 2010;16:125-142.

55. Treon SP. How I treat Waldenstrom macroglobulinemia. Blood. 2009;114(12):2375-2385.

56. Dungarwalla M, Appiah-Cubi S, Kulkarni S, et al. High-grade transformation in splenic marginal zone lymphoma with circulating villous lymphocytes: the site of transformation influences response to therapy and prognosis. Br J Haematol. 2008;143(1):71-74.

57. Baccarani U, Terrosu G, Donini A, Zaja F, Bresadola F, Baccarani M. Splenectomy in hematology: current practice and new perspectives. Haematologica. 1999;84(5):431-436.

58. Grahn SW, Alvarez J 3rd, Kirkwood K. Trends in laparoscopic splenectomy for massive splenomegaly. Arch Surg. 2006;141(8):755-761.

59. Gomez-Rubio M, Lopez-Cano A, Rendon P, et al Safety and diagnostic accuracy of percutaneous ultrasound-guided biopsy of the spleen: a multicenter study. J Clin Ultrasound. 2009;37(8):445450.

60. Howard MT, Dufresne S, Swerdlow SH, Cook JR Follicular lymphoma of the spleen: multiparameter analysis of 16 cases. Am J Clin Pathol. 2009 131(5):656-662.

61. Bendandi M. Aiming at a curative strategy for follicular lymphoma. CA Cancer J Clin. 2008;58(5): 305-317.

62. Ghielmini M, Zucca E. How I treat mantle cell lymphoma. Blood. 2009;114(8):1469-1476.

63. Fernandez V, Salamero O, Espinet B, et al. Genomic and gene expression profiling defines indolent forms of mantle cell lymphoma. Cancer Res. 2010;70(4):1408-1418.

64. Ruchlemer R, Wotherspoon AC, Thompson JN Swansbury JG, Matutes E, Catovsky D. Splenectomy in mantle cell lymphoma with leukaemia: a comparison with chronic lymphocytic leukaemia. Br J Haematol. 2002;118(2):952-958.

65. Geisler $\mathrm{CH}$, Kolstad A, Laurell A, et al. Long-term progression-free survival of mantle cell lymphoma after intensive front-line immunochemotherapy with in vivo-purged stem cell rescue: a nonrandomized phase 2 multicenter study by the Nordic Lymphoma Group. Blood. 2008;112(7):2687-2693.
66. Armitage JO. How I treat patients with diffuse large B-cell lymphoma. Blood. 2007;110(1):29-36.

67. Kan E, Levy I, Benharroch D. Splenic micronodular T-cell/histiocyte-rich large B-cell lymphoma: effect of prior corticosteroid therapy. Virchows Arch. 2009;455(4):337-341.

68. Grever MR. How I treat hairy cell leukemia. Blood. 2010;115(1):21-28.

69. Robak T, Robak P. Current treatment options in prolymphocytic leukemia. Med Sci Monit. 2007; 13(4):69-80.

70. Dungarwalla M, Matutes E, Dearden CE. Prolymphocytic leukaemia of B- and T-cell subtype: a state-of-the-art paper. Eur J Haematol. 2008; 80(6):469-476.

71. Perz J, Topaly J, Fruehauf S, Hensel M, Ho AD. Level of CD 20-expression and efficacy of rituximab treatment in patients with resistant or relapsing B-cell prolymphocytic leukemia and B-cell chronic lymphocytic leukemia. Leuk Lymphoma. 2002;43(1):149-151.

72. Osuji N, Matutes E, Tjonnfjord G, et al. T-cell large granular lymphocyte leukemia: a report on the treatment of 29 patients and a review of the literature. Cancer. 2006;107(3):570-578.

73. Lamy T, Loughran TP Jr. Clinical features of large granular lymphocyte leukemia. Semin Hematol. 2003;40(3):185-195.

74. Arcaini L, Lazzarino M, Colombo N, et al. Splenic marginal zone lymphoma: a prognostic model for clinical use. Blood. 2006;107(12):4643-4649.

75. Hermine O, Lefrere F, Bronowicki JP, et al. Regression of splenic lymphoma with villous lymphocytes after treatment of hepatitis $C$ virus infection. N Engl J Med. 2002;347(2):89-94.

76. Vallisa D, Bernuzzi $P$, Arcaini $L$, et al. Role of antihepatitis $\mathrm{C}$ virus (HCV) treatment in HCV-related, low-grade, B-cell non-Hodgkin's lymphoma: a multicenter Italian experience. J Clin Oncol. 2005; Jan 20;23(3):468-473.

77. Thieblemont C, Felman P, Callet-Bauchu E, et al. Splenic marginal-zone lymphoma: a distinct clinical and pathological entity. Lancet Oncol. 2003; 4(2):95-103.

78. Iannitto E, Minardi V, Calvaruso G, et al. Deoxycoformycin (pentostatin) in the treatment of splenic marginal zone lymphoma (SMZL) with or without villous lymphocytes. Eur J Haematol. 2005;75(2):130-135

79. Cervetti G, Galimberti S, Sordi E, et al. Significant efficacy of 2-CdA with or without rituximab in the treatment of splenic marginal zone lymphoma (SMZL). Ann Oncol. 2010;21(4):851-854.

80. Bennett M, Schechter GP. Treatment of splenic marginal zone lymphoma: splenectomy versus rituximab. Semin Hematol. 2010;47(2):143-147.

81. Tsimberidou AM, Catovsky D, Schlette E, et al. Outcomes in patients with splenic marginal zone lymphoma and marginal zone lymphoma treated with rituximab with or without chemotherapy or chemotherapy alone. Cancer. 2006;107(1):125135.

82. Iannitto $\mathrm{E}$, Luminari $\mathrm{S}$, Mammi $\mathrm{C}$, et al. Non-pegylated liposomal doxorubicin, cyclophosphamide, vincristine, prednisone and rituximab (R-COMP) as initial treatment for patients with splenic marginal zone lymphoma (SMZL): a GISL study [abstract]. Blood (ASH Annual Meeting Abstracts). 2007; 110: Abstract 1293

83. Cheson BD, Rummel MJ. Bendamustine: rebirth of an old drug. J Clin Oncol. 2009;27(9):1492-1501.

84. Robinson KS, Williams ME, van der Jagt $\mathrm{RH}$, et al. Phase II multicenter study of bendamustine plus rituximab in patients with relapsed indolent B-cell and mantle cell non-Hodgkin's lymphoma. J Clin Oncol. 2008;26(27):4473-4479.

85. Pope A. The rape of the lock. In: Miscellaneous Poems and Translations. London, United Kingdom; Bernard Lintot: 1712. 


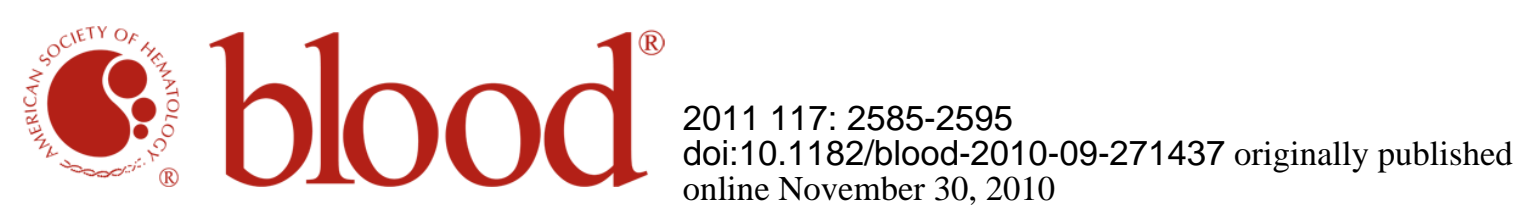

\section{How I diagnose and treat splenic lymphomas}

Emilio Iannitto and Claudio Tripodo

Updated information and services can be found at:

http://www.bloodjournal.org/content/117/9/2585.full.html

Articles on similar topics can be found in the following Blood collections

Free Research Articles (4146 articles)

How I Treat (184 articles)

Lymphoid Neoplasia (2405 articles)

Thrombocytopenia (220 articles)

Information about reproducing this article in parts or in its entirety may be found online at:

http://www.bloodjournal.org/site/misc/rights.xhtml\#repub_requests

Information about ordering reprints may be found online at:

http://www.bloodjournal.org/site/misc/rights.xhtml\#reprints

Information about subscriptions and ASH membership may be found online at:

http://www.bloodjournal.org/site/subscriptions/index.xhtml

Blood (print ISSN 0006-4971, online ISSN 1528-0020), is published weekly by the American Society of Hematology, 2021 L St, NW, Suite 900, Washington DC 20036.

Copyright 2011 by The American Society of Hematology; all rights reserved. 